\section{Embryos aren't essential to stem-cell research}

Sir - Your Editorial "Disease insights from stem cells” (Nature 422, 787; 2003) gives the impression that most US scientists support human embryonic stemcell research. Not everybody would agree; I would like to state a less reported view.

The suggestion made by some that cloned human embryos will provide otherwise unobtainable cells for disease research misleads the public. There are available countless cell lines derived from a wide variety of normal and diseased human tissues. A greater concern is the practice of understating the scientific challenges of using human embryos to produce mature adult tissues in vitro or in vivo. For embryonic stem cells to make adult tissues, they must first be converted into adult stem cells. All the fuss over embryonic stem cells has damaged public enthusiasm for any type of stem-cell research.

The US Congress should target as much as $\$ 200$ million of funding for research over the next five years to realize the promise of stem cells for human therapies. This would provide enough money for several projects at each of the 18 National Institutes of Health (NIH). This cost is a small fraction - less than $1 \%$ - of the present NIH budget (more than $\$ 27$ billion). Both adult stem-cell research and non-human embryonic stem-cell research should be supported. Nonhuman research might one day yield methods of reprogramming human cells to early developmental states without creating or destroying human embryos.

Congress should motivate stem-cell scientists to do what is in the best interest of the public. This is a necessary tension to ensure the long-term quality of the publicly funded research enterprise. As for human therapeutic cloning, the US public has been waiting a long time for leadership that is both moral and based on good science. In the long run, the best interest of the public will also be the best interest of scientists. James L. Sherley

Biological Engineering Division, Massachusetts Institute of Technology, Cambridge, Massachusetts 02139, USA

\section{US federal funding ban puts babies at risk}

Sir - We wholeheartedly agree with your Editorial "Reining in assisted reproduction" (Nature 422, 647; 2003) that more research is needed to identify and evaluate the risks that assisted reproduction may pose to children and their mothers.

\title{
Politics hindering SARS work
}

\section{Taiwan has been left to fight its outbreak with little help.}

Sir - Your News story "Taiwan left isolated in fight against SARS" (Nature 422, 652; 2003) highlights a problem scientists here have faced for years. I was invited to a workshop on mathematical ecology in Trieste in 1988, arriving only to find myself excluded from the list of participants and not allowed to give a talk.

Upon inquiry, I was told by the local organizer that "officially" I was not present at the workshop, co-sponsored by the International Atomic Energy Agency and UNESCO, owing to a protest by the Chinese Embassy in Rome after I had been invited. Apparently, unlike scientists from anywhere else, all Chinese scientists had to be recommended by the Chinese government to attend that workshop, and since Taiwan was considered to be part of China, I could not attend without permission from the Chinese government.

The SARS epidemic illustrates that being politically correct in scientific matters does more than just inconvenience a few Taiwanese scientists. Indeed, with the official global death toll from SARS at 643 by 19 May and rising fast, one can only speculate how many lives could have been saved had the health officials in Hong Kong been a little less worried about being politically correct in dealing with the emergence of this epidemic.

It is incredible that, even now, with the SARS death toll in Hong Kong having reached 247 by 18 May, officials there still refuse to link the problem with Hong Kong's proximity to Guangdong Province in China, where similar symptoms have been appearing since November. Almost all early infections in Hong Kong can be traced to recent travellers from China or people in close contact with them.

The World Health Organization sent two epidemiologists to Taiwan to assess the situation on 3 May. Meanwhile, left to fight SARS alone, Taiwan had a threefold rise in the number of cases in April and by 19 May had had 344 probable cases and 40 deaths.

Unfortunately, the Hong Kong government seems more preoccupied with how it looks to China and the rest of the world than with saving lives.

Ying-Hen Hsieh

Department of Applied Mathematics, National Chung Hsing University,

250 Kuo-Kuang Road, Taichung, Taiwan 402
In the United States, a ban on federal funding for embryo research makes this work especially difficult. Lifting this ban would both enable more outcome studies and ensure that research on new treatments would be subject to federal supervision and would be conducted in accordance with human-research subject protections under the common rule.

In the United Kingdom and other European countries, patients benefit from state-supported healthcare systems that subsidize and regulate the treatment for infertility and assisted-reproductive technologies. Unfortunately, most patients in the United States pay for their expensive treatments out of their own pockets. Sometimes, parents' desire to maximize their chances of having a baby and their interest in minimizing risk to themselves and their offspring are in conflict.

We have doubts as to whether a system analogous to the United Kingdom's Human Fertilisation and Embryology Authority is appropriate in the United States, where citizens fervently guard their rights to privacy and reproductive choice.

Many would see a government body with the power to dictate treatment choices as an unwarranted imposition and intrusion, especially because the government does not subsidize payment for their treatment.

Proactive, responsible self-regulation is the key to ensuring patient safety. The American Society for Reproductive Medicine (ASRM) guides medical practice and research and keeps members abreast of the ethical issues arising daily in reproductive medicine; the Society for Assisted Reproductive Technology (SART) sets the standards for assistedreproductive technology clinics, including laboratory certification, reporting of clinic success rates and compliance with the ASRM guidelines. This voluntary yet effective procedure reflects the dedication of our members to assuring safety, efficacy and confidentiality for all our patients.

We hope that the US government will one day fund research in this field, with accompanying protection. In the meantime, we appreciate our international colleagues whose research informs our own work.

Sandra Carson ${ }^{\star}$, Robert Brzyski $\dagger$

${ }^{*}$ President, American Society for Reproductive Medicine (ASRM), 1209 Montgomery Highway, Birmingham, Alabama 35216, USA $\dagger$ President, Society for Assisted Reproductive Technology (SART), 1209 Montgomery Highway, Birmingham, Alabama 35216, USA 